\title{
Effect of exogenous gonadotrophins on oestrus, the LH surge and the timing and rate of ovulation in red deer (Cervus elaphus)
}

\author{
H. N. Jabbour ${ }^{1 *}$, F. A. Veldhuizen ${ }^{1}$, R. C. Mulley $^{2}$ and \\ G. W. Asher ${ }^{1}$ \\ ${ }^{1}$ Ruakura Agricultural Centre, Ministry of Agriculture and Fisheries, Private Bag, Hamilton, \\ New Zealand; and ${ }^{2}$ Faculty of Agriculture and Rural Development, University of Western \\ Sydney, Richmond, NSW 2735, Australia
}

\begin{abstract}
Red deer hinds $(n=38)$ were treated in the breeding season with five different gonadotrophin regimens to investigate the temporal relationship between oestrus, ovulation and the LH surge. All hinds were treated with progesterone-impregnated controlled internal drug release (CIDR) devices to synchronize oestrus. The five treatments were as follows: treatment 1 , controls; treatments 2, 3 and 4, 1200 iu pregnant mares' serum gonadotrophin (PMSG) was administered i.m. $72 \mathrm{~h}$ before CIDR device withdrawal (treatments 3 and 4 were also injected i.v. with $0.4 \mathrm{mg}$ synthetic GnRH 12 or $18 \mathrm{~h}$ after CIDR device withdrawal, respectively); treatment 5, $200 \mathrm{iu}$ PMSG was administered i.m. $72 \mathrm{~h}$ before CIDR device withdrawal and $0.5 \mathrm{iu}$ FSH was administered in eight equal doses at intervals of $12 \mathrm{~h}$ starting from the time of PMSG injection. The hinds were run with crayonharnessed stags to determine the time of oestrus onset. Blood samples were collected every 2 days for 26 days after CIDR device removal to determine concentrations of plasma progesterone and every $2 \mathrm{~h}$ for $72 \mathrm{~h}$ after CIDR device removal to determine plasma $\mathrm{LH}$ profiles. Laparoscopy for ovary examination was performed 6 or $12 \mathrm{~h}$ after oestrus onset and was repeated twice at intervals of $12 \mathrm{~h}$. Final ovulation rate was determined on day 7 after CIDR device removal. All hinds received $500 \mu \mathrm{g}$ cloprostenol i.m. on day 13. A total of 30 and 34 hinds exhibited oestrus and ovulation, respectively. Exogenous gonadotrophin administration advanced the onset of oestrus $(21.1 \pm 1.9 \mathrm{~h}$ versus $43.6 \pm 2.6 \mathrm{~h}, P<0.001)$ and ovulation $(41.8 \pm 3.1 \mathrm{~h}$ versus $71.3 \pm 5.8 \mathrm{~h}, P<0.001)$ and reduced the interval between the two events $(19.1 \pm 1.8 \mathrm{~h}$ versus $33.0 \pm 0.0 \mathrm{~h}, P<0.01)$. Treatment with CIDR devices alone resulted in one $(n=6)$ or two $(n=1)$ ovulation points. Exogenous gonadotrophins induced multiple ovulation points in most hinds. $\mathrm{GnRH}$ administration reduced the period over which multiple ovulations occurred to $\leq 12 \mathrm{~h}$, whereas PMSG or PMSG and FSH induced ovulation over a period $>24 \mathrm{~h}$. Treatment with exogenous gonadotrophins advanced the mean time to peak $\mathrm{LH}(17.1 \pm 1.7 \mathrm{~h}$ versus $48.0 \pm 3.1 \mathrm{~h}, P<0.01)$ but had no effect on mean peak LH concentrations. Two hinds showed premature luteal regression. The administration of $\mathrm{PGF}_{2 \alpha}$ was effective in terminating luteal activity of multiple corpora lutea: progesterone concentration declined from $8.8 \pm 1.4$ to $0.6 \pm 0.1 \mathrm{ng} \mathrm{ml}^{-1}$ within 2 days of prostaglandin administration.
\end{abstract}

\section{Introduction}

The application of reproductive technology as a tool for conservation of endangered cervid species and introduction of diverse genetic material into captive populations has gained considerable popularity in the past decade. Most efforts have concentrated on propagation of male gametes by developing protocols for artificial insemination. Conception rates in the

*Present address and reprint requests: The Zoological Society of London, Institute of Zoology, Regent's Park, London NW1 4RY, UK. Received 24 June 1993. range of $50-70 \%$ are commonly achieved in red (Fennessy et al., 1990), fallow (Asher et al., 1988, 1992b; Mulley et al., 1988) and Eld's deer (Monfort et al., 1993) following intrauterine insemination. Moreover, high fertility rates $(70-80 \%)$ have been demonstrated in fallow deer (Jabbour et al., 1993) and white-tailed deer (Magyar et al., 1989) following cervical insemination.

Treatments to induce and increase ovulation rate have been applied to cervid species including red deer (Jabbour et al., 1990; Asher et al., 1992a), fallow deer (Jabbour et al., 1990), Père David's deer (Argo et al., 1994), white-tailed deer (Magyar et al., 1990) and chital deer (Mylrea et al., 1991). These 
treatments comprise the administration of pregnant mares' serum gonadotrophin (PMSG) or FSH. PMSG, a hormone with a long half-life (McIntosh et al., 1975), is usually administered in a single injection and this has resulted in more widespread application of the gonadotrophin in superovulation and embryo transfer programmes. However, as observed with domestic species, the use of superovulatory doses of PMSG alone results in ovarian overstimulation and a low recovery rate of oocytes (sheep: Jabbour and Evans, 1991a; fallow deer: Thompson and Asher, 1988). This has been attributed to a high concentration of oestrogen, which may result from a large number of follicles failing to rupture (Ryan et al., 1984; Jabbour and Evans, 1991a), a second wave of follicular growth stimulated after ovulation (Bouters et al., 1983) or an increase in oestrogen secretion by follicles following stimulation with PMSG (Jabbour and Evans, 1991a).

The following study was designed to investigate the effect of PMSG administered alone or in combination with FSH or $\mathrm{GnRH}$ on the endocrine changes and the timing, duration and rate of ovulation in adult parous red deer hinds during the breeding season. The sensitivity of multiple corpora lutea to prostaglandin treatment on day 13 of the oestrous cycle was also determined by monitoring progesterone profiles.

\section{Materials and Methods}

\section{Animals and management}

A total of 38 parous red deer hinds and four mature entire stags were used between March and April 1990 in the North Island of New Zealand $\left(37^{\circ} 46^{\prime} \mathrm{S}, 175^{\circ} 20^{\prime} \mathrm{E}\right)$. The animals were always held in four separate groups (A-D, $n=9-10$ hinds) each with a separate mature stag, from the time of commencement of treatments. Each group had animals representative of each of the five treatment regimens, which were balanced for liveweight (overall mean \pm SEM of $89.38 \pm 1.4 \mathrm{~kg}$ ). Treatment schedules were staggered 2 days between consecutive groups to restrict the number of hinds undergoing laparoscopy on any one day. The deer were contained in high-fenced paddocks $\left(2500 \mathrm{~m}^{2}\right)$ and grazed on ryegrass-clover pastures. Meadow hay was provided ad libitum and occasional feeding of whole kernel maize was used to habituate the deer to their handlers.

\section{Hormone administration}

Single controlled internal drug release (CIDR) devices (type-G, $0.3 \mathrm{~g}$ progesterone per device, Agricultural Division, $\mathrm{CHH}$ Plastic Products Group Ltd, Hamilton) were inserted intravaginally for a total period of 14 days from 21-27 March until 4-10 April inclusive. The devices were replaced with a new one in each animal on day 10 (31 March-6 April inclusive) to ensure that progesterone concentration remained high throughout the CIDR device insertion period. Hinds undergoing treatment $I(n=8)$ served as controls, hinds subjected to treatments $2(n=7), 3(n=8)$ and $4(n=8)$ received a single i.m. injection of 1200 iu PMSG (Folligon: Intervet, Lane Cove, NSW) administered $72 \mathrm{~h}$ before CIDR device withdrawal. Hinds undergoing treatments 3 and 4 were also injected i.v. with $0.4 \mathrm{mg}$ synthetic GnRH (Gonadorelin:
Fertagyl, Intervet) 12 or $18 \mathrm{~h}$ after CIDR device withdrawal, respectively. Hinds undergoing treatment $5(n=7)$ received an i.m. injection of 200 iu PMSG $72 \mathrm{~h}$ before CIDR device withdrawal and 0.5 iu ovine FSH (Ovagen: Immunochemical Products Ltd, Auckland) administered i.m. in eight equal doses $(0.0625 \mathrm{iu})$, starting at the time of PMSG administration and finishing $12 \mathrm{~h}$ after CIDR device withdrawal. All hinds were injected i.m. with $500 \mu \mathrm{g}$ prostaglandin $\mathrm{F}_{2 \alpha}$ analogue (Cloprostenol: Imperial Chemical Industries, Cheshire) on day 13 after CIDR device withdrawal.

\section{Detection of oestrus}

Each of the stags was fitted for 4 days with a ram mating harness (Fergus: Merck, Sharpe and Dohme NZ Ltd, Auckland) that contained a red crayon. Observations for crayon mating marks were conducted every $2 \mathrm{~h}$ during the $72 \mathrm{~h}$ after CIDR device withdrawal by close inspection of each hind. Crayons were replaced every 8-12 h.

\section{Collection of blood samples}

A total of 18 hinds (groups A and D, $n=4$ for treatments 1 , 2 and 3 and $n=3$ for treatments 4 and 5) were mustered into a covered shed, individually restrained in a pneumatically controlled cradle and blood samples taken by jugular venepuncture (in $10 \mathrm{ml}$ heparinized vacutainers) every 2-3 days from the time of CIDR device withdrawal until 26 days later. Intensive blood samples were also collected every $2 \mathrm{~h}$ for $72 \mathrm{~h}$ after CIDR device withdrawal from the right external jugular vein via indwelling catheters (Intracath 3122: Deseret Company, Sandy, UT) that had been inserted about 2-4 h before the start of blood sampling. Blood samples were also collected every $20 \mathrm{~min}$ for $4 \mathrm{~h}$ from hinds that were treated with GnRH. Restraint was not necessary for intensive blood samplings; blood was withdrawn while groups of hinds were held in $2.4 \mathrm{~m}^{2}$ pens after repeated mustering from nearby paddocks. Blood samples were centrifuged at $1000 \mathrm{~g}$ for 25 min immediately after collection and the plasma aliquots stored at $-20^{\circ} \mathrm{C}$ until assayed.

\section{Assessment of time, duration and rate of ovulation}

Hinds within each treatment were allocated randomly for initial ovarian examination by laparoscopy 6 or $12 \mathrm{~h}$ after the time of onset of oestrus. Laparoscopy was repeated twice at intervals of $12 \mathrm{~h}$ and the numbers of corpora haemorrhagica were recorded at each inspection time. The duration of ovulation was taken to be the period in which total ovulation rate increased between consecutive laparoscopies, and was estimated to be $>24 \mathrm{~h}$ in animals in which ovulation rate on day 7 was greater than that observed 30 or $36 \mathrm{~h}$ after the onset of ovulation. Hinds that did not display oestrus were inspected $72 \mathrm{~h}$ after CIDR device withdrawal. The final ovarian response was determined in all hinds on day 7 after CIDR device withdrawal.

Laparoscopy was performed under sedation after injecting $1.0-2.0 \mathrm{mg}$ xylazine hydrochloride $\mathrm{kg}^{-1}$ liveweight (Rompun: Bayer, Leverkusen) i.m. A presurgical clip and scrub was carried 
Table 1. Incidence of oestrus and ovulation and its duration among red deer hinds

\begin{tabular}{lcccccc}
\hline Treatment & $\begin{array}{c}\text { Incidence of } \\
\text { oestrus }\end{array}$ & $\begin{array}{c}\text { Incidence of } \\
\text { ovulation }\end{array}$ & $\begin{array}{c}\text { Duration of } \\
\text { ovulation (h) }\end{array}$ & $\begin{array}{c}\text { Number with } \\
\text { one ovulation }\end{array}$ & $\begin{array}{c}\text { Number with } \\
\text { two ovulations }\end{array}$ & $\begin{array}{c}\text { Number with } \\
>2 \text { ovulations }\end{array}$ \\
\hline CIDR device alone & $6 / 8$ & $7 / 8$ & - & 6 & 1 & 0 \\
CIDR + PMSG & $6 / 7$ & $7 / 7$ & $>24$ & 1 & 0 & 6 \\
CIDR + PMSG + GnRH (12 h) & $6 / 8$ & $8 / 8$ & $\leq 12$ & 1 & 0 & 7 \\
CIDR + PMSG + GnRH (18 h) & $5 / 8$ & $6 / 8$ & $\leq 12$ & 1 & 1 & 4 \\
CIDR + PMSG + FSH & $7 / 7$ & $6 / 7$ & $>24$ & 0 & 0 & 6 \\
\hline
\end{tabular}

CIDR: controlled internal drug release; PMSG: pregnant mares' serum gonadotrophin.

out in the midline anterior to the udder, and local anaesthetic (Lignocaine: $2 \%$ lignocaine hydrochloride; Delta Veterinary Laboratories, NSW) was administered at the insertion points of the trocars. Sedation was reversed by injecting $0.5 \mathrm{mg}$ yohimbine hydrochloride $\mathrm{kg}^{-1}$ liveweight (Recervyl: Aspiring Animal Services, Wanaka) i.m. External puncture wounds were treated with topical antibiotic powder (Aureomycin: Cyanamid NZ Ltd, Auckland) and $10 \mathrm{ml}$ of long-acting antibiotic preparation (Propen LA: Glaxo NZ Ltd, Auckland) was administered every $48 \mathrm{~h}$ until cessation of laparoscopy.

\section{Hormone assays}

Blood samples collected every 2-3 days were assayed for progesterone, and intensively collected blood samples were assayed for $\mathrm{LH}$. Concentrations of progesterone were measured in plasma in duplicate by direct radioimmunoassay as described for red deer by Asher (1990). All of the plasma samples from an individual hind were included within a single assay. Samples with low, medium and high concentrations of progesterone were included as control samples at frequent intervals in each assay. The interassay coefficients of variation were $24.1 \%$ for the low control (mean, $0.5 \mathrm{ng} \mathrm{ml}^{-1}$ ), $12.7 \%$ for the medium control (mean, $5.4 \mathrm{ng} \mathrm{ml}^{-1}$ ) and $15.2 \%$ for the high control (mean, $10.8 \mathrm{ng} \mathrm{ml}^{-1}$ ) samples. The intra-assay coefficients of variation were $6.8 \%, 7.4 \%$ and $4.9 \%$ for the three control samples, respectively. Sensitivity of the assay, defined as the first point that was significantly different from zero, was $0.10 \mathrm{ng} \mathrm{ml}^{-1}$.

Plasma LH concentrations were determined in duplicate by a heterologous radioimmunoassay that was described for sheep by Scaramuzzi et al. (1970) and validated for red deer plasma by Kelly et al. (1982). The ovine pituitary LH preparation used for standards and iodinated tracer was NIH-LH-SII (National Hormone and Pituitary Programme, University of Maryland, MD). The LH antibody, which had been raised in a rabbit using $\mathrm{NIH-LH-S1I}$ as the antigen, was used in the assay at a final dilution of 1:200 000. Crossreactivity with other proteins has been described by Kelly et al. (1982). All the samples from a single hind were included within the same assay. Samples with low, medium and high concentrations of cervine $\mathrm{LH}$ were included as control samples at regular intervals in each assay. The inter-assay coefficients of variation were $23.9 \%$ for the low control (mean, $1.0 \mathrm{ng} \mathrm{ml}^{-1}$ ), $4.4 \%$ for the medium control (mean, $5.4 \mathrm{ng} \mathrm{ml}^{-1}$ ) and $6.9 \%$ for the high control (mean $9.3 \mathrm{ng} \mathrm{ml}^{-1}$ ). The intra-assay coefficients of variation were $19.0 \%, 7.5 \%$ and $4.3 \%$ for the same control samples, respectively. The sensitivity of the assay was $0.03 \mathrm{ng} \mathrm{NIH-LH-}$ S11 $\left(0.30 \mathrm{ng} \mathrm{ml}^{-1}\right)$.

\section{Statistical analyses}

Data are presented as mean \pm SEM within each treatment and were analysed by $\chi^{2}$ tests and analysis of variance. Mean LH profiles were obtained by normalizing the data about the time of the LH surge peak.

\section{Results}

\section{Oestrus and ovulation}

Of the 38 hinds in the trial, a total of 30 and 34 exhibited oestrus and ovulated, respectively (Table 1 ). There was no difference between treatments on the incidence of oestrus or ovulation. However, the administration of exogenous gonadotrophins compared with CIDR treatment alone advanced the time to onset of oestrus $(21.1 \pm 1.9 \mathrm{~h}$ versus $43.6 \pm 2.6 \mathrm{~h}$, $P<0.001)$ and ovulation $(41.8 \pm 3.1 \mathrm{~h}$ versus $71.3 \pm 5.8 \mathrm{~h}$, $P<0.001)$ and reduced the interval between the two events (19.1 $\pm 1.8 \mathrm{~h}$ versus $33.0 \pm 0.0 \mathrm{~h}, P<0.01$, Table 2 ).

Treatment with CIDR devices alone resulted in one $(n=6)$ or two $(n=1)$ ovulation points. Treatment with exogenous gonadotrophins increased the total follicular response and numbers of corpora lutea $(P<0.01$, Table 3$)$. The majority of the hinds treated with PMSG with or without FSH had multiple corpora lutea (Table 1), with final ovulation rates ranging from 1 to 23,1 to 17,1 to 12 and 0 to 19 for hinds treated with PMSG, PMSG and GnRH at $12 \mathrm{~h}$, PMSG and $\mathrm{GnRH}$ at $18 \mathrm{~h}$, and PMSG and FSH, respectively. The administration of GnRH reduced the duration of multiple ovulation to $\leq 12 \mathrm{~h}$, whereas hinds treated with PMSG or PMSG and FSH ovulated over a period $>24 \mathrm{~h}$.

\section{Endocrine response}

Plasma LH profiles normalized around the $\mathrm{LH}$ peak for the various treatments are presented in Fig. 1. (One hind treated with CIDR devices alone that showed no increase in $\mathrm{LH}$ concentration and failed to exhibit oestrous behaviour or to ovulate was excluded from the analyses.) Treatment with exogenous gonadotrophins advanced the mean time to LH 
Table 2. Mean ( \pm SEM) times to onset of oestrus and ovulation in red deer from removal of CIDR devices and the mean interval between the two events

\begin{tabular}{lccc}
\hline Treatment & $\begin{array}{l}\text { Time of onset } \\
\text { of oestrus }(\mathrm{h})\end{array}$ & $\begin{array}{l}\text { Time to first } \\
\text { ovulation }(\mathrm{h})\end{array}$ & $\begin{array}{c}\text { Interval from oestrus } \\
\text { to ovulation (h) }\end{array}$ \\
\hline CIDR device alone & $43.6 \pm 2.6$ & $71.3 \pm 5.8$ & $33.0 \pm 0.0$ \\
CIDR + PMSG & $16.6 \pm 2.7$ & $31.0 \pm 5.7$ & $14.0 \pm 4.6$ \\
CIDR + PMSG + GnRH (12 h) & $23.0 \pm 4.7$ & $53.0 \pm 5.6$ & $24.0 \pm 2.7$ \\
CIDR + PMSG + GnRH (18 h) & $21.6 \pm 3.7$ & $34.5 \pm 3.8$ & $15.0 \pm 1.7$ \\
CIDR + PMSG + FSH & $22.9 \pm 4.2$ & $46.3 \pm 4.1$ & $22.0 \pm 2.9$ \\
\hline
\end{tabular}

CIDR: controlled internal drug release; PMSG: pregnant mares' serum gonadotrophin.

Table 3. The ovarian response of red deer hinds following stimulation with CIDR devices and exogenous gonadotrophins

\begin{tabular}{lccc}
\hline Treatment & $\begin{array}{c}\text { Total number } \\
\text { of follicles }\end{array}$ & $\begin{array}{c}\text { Number of large } \\
\text { unruptured follicles }\end{array}$ & $\begin{array}{c}\text { Number of } \\
\text { corpora lutea }\end{array}$ \\
\hline CIDR device alone & $1.4 \pm 0.3$ & $0.4 \pm 0.3$ & $1.0 \pm 0.2$ \\
CIDR + PMSG & $10.7 \pm 4.1$ & $2.3 \pm 0.5$ & $8.4 \pm 2.7$ \\
CIDR + PMSG + GnRH $(12 \mathrm{~h})$ & $9.1 \pm 2.2$ & $1.6 \pm 0.3$ & $7.5 \pm 2.1$ \\
CIDR + PMSG + GnRH $(18 \mathrm{~h})$ & $6.5 \pm 1.3$ & $2.4 \pm 0.7$ & $4.3 \pm 1.5$ \\
CIDR + PMSG + FSH & $12.7 \pm 1.7$ & $4.0 \pm 1.1$ & $8.7 \pm 2.3$ \\
\hline
\end{tabular}

Values are means \pm SEM.

CIDR: controlled internal drug release; PMSG: pregnant mares' serum gonadotrophin.

peak $(17.1 \pm 1.7 \mathrm{~h}$ versus $48.0 \pm 3.1 \mathrm{~h}, P<0.01)$, but had no effect on the mean peak $\mathrm{LH}$ concentrations. The overall mean peak $\mathrm{LH}$ concentration was $40.1 \pm 4.6 \mathrm{ng} \mathrm{ml}^{-1}$. There was no apparent effect of GnRH administration on the mean time to $\mathrm{LH}$ peak. However, all hinds treated with $\mathrm{GnRH} 12$ or $18 \mathrm{~h}$ after CIDR device withdrawal had LH peaks 14 or $20 \mathrm{~h}$ after CIDR device withdrawal, respectively $(2 \mathrm{~h}$ after injection of $\mathrm{GnRH})$. In contrast, the range in the timing of the LH peak for hinds treated with CIDR devices, PMSG or PMSG and FSH was $42-52 \mathrm{~h}, 10-12 \mathrm{~h}$ or $12-36 \mathrm{~h}$ after CIDR device withdrawal, respectively. The occurrence of oestrus varied in relation to the preovulatory $\mathrm{LH}$ surge, ranging from $38 \mathrm{~h}$ before to $24 \mathrm{~h}$ after the LH peak. The timing of ovulation ranged from 2 to $42 \mathrm{~h}$ after the LH peak.

The mean concentration of progesterone at the time of CIDR device withdrawal was $2.5 \pm 0.2 \mathrm{ng} \mathrm{ml}^{-1}$. Luteal development was evident in all hinds after increasing the plasma concentration of progesterone starting on day 4 after CIDR device withdrawal. Peak concentration of progesterone for mono-ovulating hinds was $2.9 \pm 1.3 \mathrm{ng} \mathrm{ml}^{-1}$. However, in hinds treated with exogenous gonadotrophins, there was a positive increase in progesterone concentrations with increasing numbers of corpora lutea $(P<0.05)$. The overall peak progesterone concentration for superovulated hinds (treatments $2-5$ inclusive) was $11.4 \pm 2.1 \mathrm{ng} \mathrm{ml}^{-1}$. Two hinds treated with PMSG or PMSG and GnRH after $12 \mathrm{~h}$ showed premature luteal regression (following detection of three corpora lutea and multiple large follicles in each hind) as revealed by a decline in progesterone secretion after day 7 following removal of CIDR devices. Treatment with prostaglandin on day 13 of the oestrous cycle resulted in reduced plasma progesterone concentrations in hinds from all treatment groups (Fig. 2). Progesterone concentrations declined from a peak of $8.8 \pm 1.4$ to $0.6 \pm 0.1 \mathrm{ng} \mathrm{ml}^{-1}$ within 2 days of prostaglandin administration.

\section{Discussion}

The average intervals between withdrawal of progesterone implants and oestrus or ovulation are similar to those reported previously for red deer (Asher et al., 1992a) and fallow deer (Jabbour et al., 1993). Treatment with CIDR devices alone was effective in inducing oestrus and ovulation in most of the hinds. This result is in contrast to a previous report in which oestrus and ovulation failure was observed in most $(75 \%)$ of the hinds treated with CIDR devices alone (Asher et al., 1992a). This finding suggests subtle seasonal effects on oestrous synchrony in red deer hinds. The present study was conducted approximately 2 weeks later than that reported by Asher et al. (1992a). The administration of exogenous gonadotrophins significantly advanced the time to onset of oestrus and ovulation following withdrawal of CIDR devices (Thompson et al., 1990). This finding is similar to reports in superovulated sheep following oestrus synchronization with CIDR devices. PMSG enhances the recruitment of follicles and steroidogenesis (Jabbour and Evans, 1991a) by acting directly on the ovary. This presumably results in an earlier attainment than usual of threshold concen- 

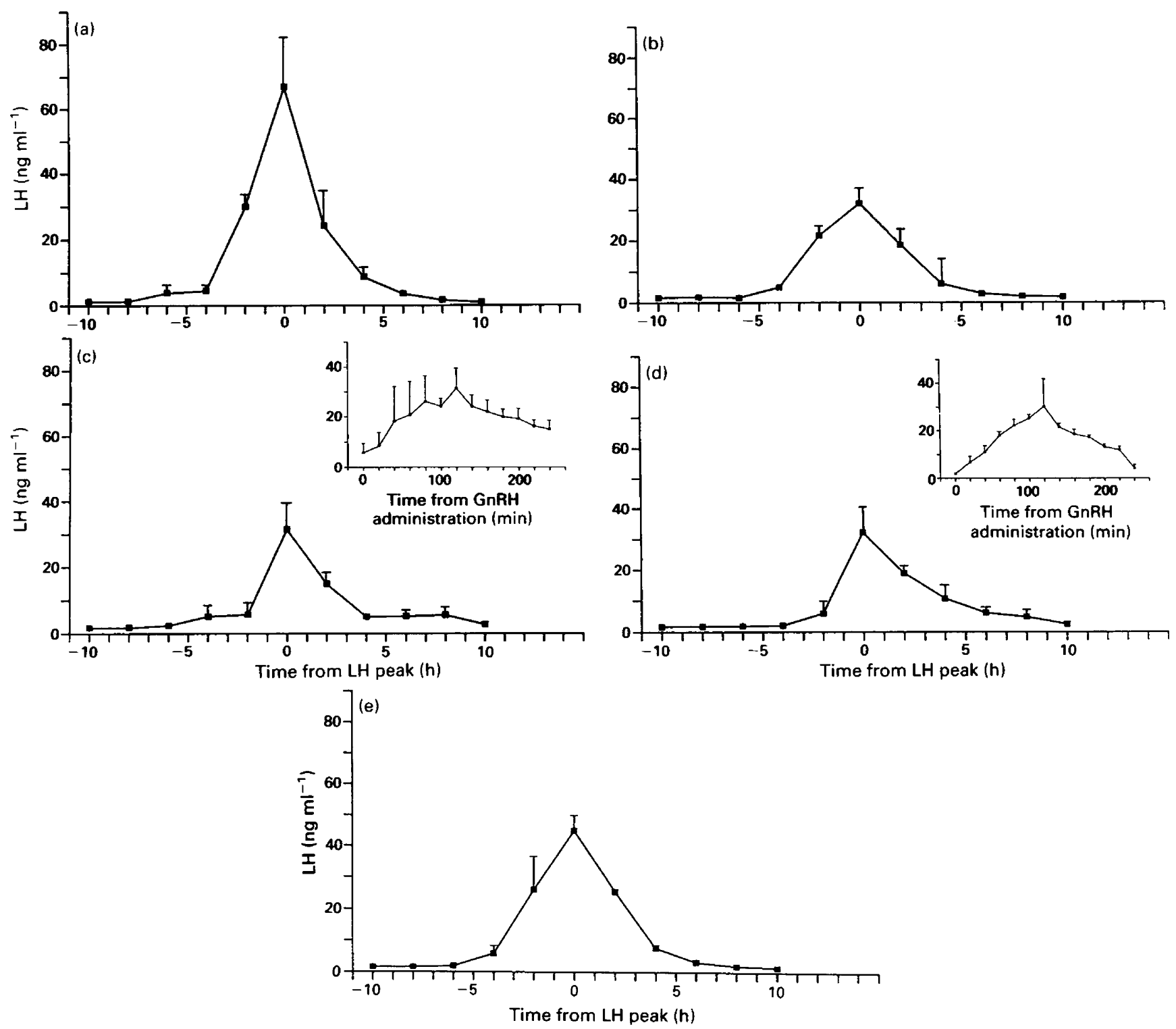

Fig. 1. Profiles of mean ( \pm SEM) plasma LH concentration normalized around LH peak in red deer hinds following treatment with (a) CIDR devices alone $(n=3)$, or with (b) 1200 iu pregnant mares' serum gonadotrophin (PMSG) $(n=4) ; 1200$ iu PMSG and GnRH administered (c) 12 h ( $n=4)$ or (d) $18 \mathrm{~h}$ after CIDR device withdrawal $(n=3)$; (e) 200 iu PMSG and 0.5 iu ovine FSH $(n=3$ ).

trations of oestrogen required for overt oestrous behaviour and initiation of the pre-ovulatory LH surge.

The use of exogenous gonadotrophins for superovulation has been attempted in a number of cervid species (e.g. fallow deer: Jabbour et al., 1990; red deer: Jabbour et al., 1990; Asher et al., 1992a; Argo et al., 1994; Père David's deer: Argo et al., 1994). However, this has always resulted in disappointing recovery and fertilization rates of oocytes (Jabbour et al., 1990; Argo et al., 1994). This has been attributed to recruitment of multiple follicles over an extended period after withdrawal of CIDR devices. In this study, this contention is further supported by the observation that, in hinds treated with PMSG alone, the number of ovulations on day 7 was higher than after the last laparoscopy performed during the $72 \mathrm{~h}$ after CIDR device removal, which may result in excessive secretion of oestrogen. Argo et al. (1994) demonstrated in red deer and Père David's deer that follicular development and consequently oestrogen secretion commenced before the termination of oestrous synchronization treatment. This may ultimately accelerate the transport of gametes through the reproductive tract. Embryos or ova arriving prematurely in the uterus will degenerate and be expelled promptly via the cervix (Whyman and Moor, 1980).

Alternatively, the extended duration of ovulation may contribute to the reduced fertilization rates observed in superovulated fallow deer (HN Jabbour, unpublished), red deer and Père David's deer (Argo et al., 1994). This may necessitate a double insemination regimen to ensure that viable spermatozoa are present when oocytes are shed from a second follicular wave. This hypothesis is supported by other studies in which 


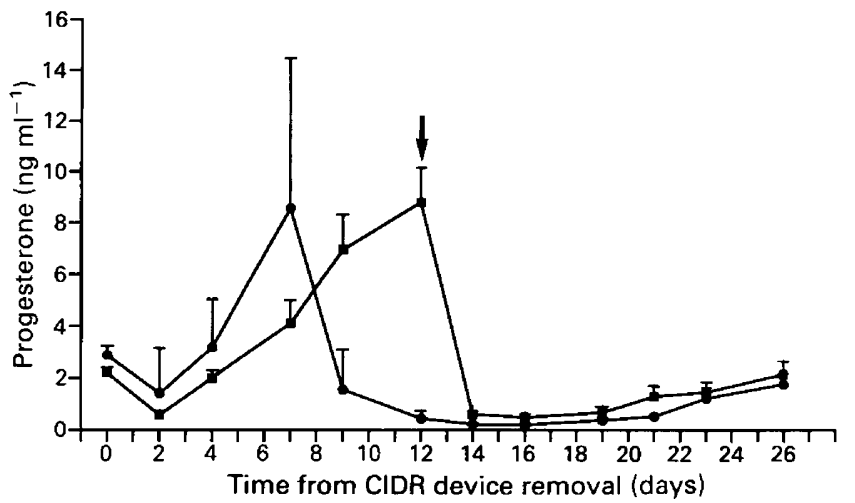

Fig. 2. Profiles of mean ( \pm SEM) plasma progesterone after withdrawal of CIDR devices in red deer hinds from all treatment groups ( $n=15 ;-n=2$ hinds that underwent premature luteal regression). The arrow denotes the time of prostaglandin administration.

embryos were recovered at disparate stages of development following superovulation of red and Père David's deer (Argo et al., 1994). This problem may be overcome by the administration of $\mathrm{GnRH} 12 \mathrm{~h}$ after CIDR device withdrawal, which results in more synchronous timing of ovulation in a cohort of hinds and may also reduce the secretion of oestradiol, as has been demonstrated in sheep (Jabbour and Evans, 1991b).

The administration of GnRH had no effect on the peak LH concentration, suggesting that in intact hinds the positive feedback response of oestrogen on the hypothalamus-pituitary axis is an all-or-none response. Such a result is similar to reports that increasing doses of PMSG failed to increase LH secretion in sheep (Evans and Robinson, 1980). However, it contradicts reports that in ovariectomized fallow deer (Jabbour et al., 1992) an increase in the magnitude of the $\mathrm{LH}$ surge occurs with increasing doses of oestradiol benzoate administered by injection. In the study described here, treatment with GnRH resulted in more synchronous timing of the LH surge, which ultimately reduced the spread in the timing of ovulation. The timing of ovulation in relation to the LH peak was not constant in the different treatment groups and in one hind ovulation was observed as early as $2 \mathrm{~h}$ after the $\mathrm{LH}$ peak. This finding suggests that ovulation may result from a direct action of PMSG on the ovary (Cameron and Batt, 1991), and is supported by observations in fallow deer in which ovulation and premature luteinization of follicles in some females was induced in the complete absence of an LH surge (Jabbour et al., 1993).

The relationship between the number of corpora lutea and plasma progesterone concentrations during the luteal phase is in agreement with the findings of Kelly et al. (1982) and Asher et al. (1992a). This provides further evidence that luteal tissue is the principal source of progesterone during the oestrous cycle of red deer (Adam et al., 1985). The administration of prostaglandin on day 13 of the oestrous cycle was effective in reducing plasma progesterone concentration within 2 days. This result suggests effective demise of the corpora lutea in superovulated hinds. Return to oestrus was not monitored in this study. However, Asher et al. (1992a) reported that return to oestrus occurred over 7 days after prostaglandin administration to a group of superovulated hinds.
The reason for the occurrence of premature luteal regression is not clear. It may be related to excessive follicular stimulation or high circulating concentrations of oestrogen during the early luteal phase (Armstrong et al., 1982). In sheep, the incidence of premature luteal regression was associated with secondary peaks of oestrogen secretion after the LH surge (Jabbour and Evans, 1991a). The secondary oestrogen peaks may have induced a premature luteolytic process; whether this is a direct or indirect action is unclear. Wiltbank (1966) and Schoonmaker et al. (1982) reported early regression of the corpus luteum in Hereford heifers and Rhesus monkeys, respectively, following exogenous injection of oestrogen shortly after ovulation. Schoonmaker et al. (1982) speculated that in the Rhesus monkey oestrogen may act on the hypothalamo-hypophyseal axis to inhibit LH secretion, thus denying the corpus luteum necessary luteotrophic support. However, it is possible that excessive amounts of oestrogen stimulate the secretion of luteolytic prostaglandin. Battye et al. (1988) reported that the administration of flunixin meglumine, an inhibitor of prostaglandin synthetase, prevented premature luteal regression in PMSG-treated goats.

The authors would like to acknowledge the assistance of J. F. Smith, H. Tervit, J. Parr, P. Kirton, and C. J. Morrow.

\section{References}

Adam CL, Moir CE and Atkinson T (1985) Plasma concentration of progesterone in female red deer (Cervus elaphus) during the breeding season, pregnancy and anoestrus Joumal of Reproduction and Fertility 74 631-636

Argo C McG, Jabbour HN, Goddard PJ, Webb R and Loudon ASI (1994) Superovulation in red deer (Cervus elaphus) and Père David's deer (Elaphurus davidianus) and fertilization rates following artificial insemination with Père David's deer semen Joumal of Reproduction and Fertility 100 629-636

Armstrong DT, Miller BG, Walton EA, Pfitzner AP and Warnes GM (1982) Endocrine response and factors which limit the response of follicles to PMSG and FSH. Embryo Transfer in Cattle, Sheep and Goats pp 8-15 Eds IN Shelton, AO Trounson, NW Moore and IW James. Australian Society for Reproductive Biology, Canberra

Asher GW (1990) Effect of subcutaneous melatonin implants on the seasonal attainment of puberty in female deer (Cervus elaphus) Animal Reproduction Science 22 145-159

Asher GW, Adam JL, James RW and Barnes D (1988) Artificial insemination of farmed fallow deer (Dama dama): fixed time insemination at a synchronized oestrus Animal Reproduction Science 47 487-492

Asher GW, Fisher MW, Jabbour HN, Smith JF, Mulley RC, Morrow CJ, Veldhuizen FA and Langridge M (1992a) Relationship between the onset of oestrus, the preovulatory surge in luteinizing hormone and ovulation following oestrus synchronization and superovulation of farmed red deer (Cerous elaphus) Journal of Reproduction and Fertility 96 261-273

Asher GW, Morrow CJ, Jabbour HN, Mulley RC, Veldhuizen FA and Langridge M (1992b) Laparoscopic intrauterine insemination of fallow deer with frozenthawed or fresh semen after synchronization with CIDR devices New Zealand Veterinary Joumal 40 8-14

Battye KM, Fairclough RJ, Cameron AWM and Trounson AO (1988) Evidence for prostaglandin involvement in early luteal regression of the superovulated nanny goat (Capra hircus) Journal of Reproduction and Fertility 84 425-430

Bouters R, Moyaert I, Corijn M and Vandeplassche M (1983) The use of PMSG antisenum in superovulated cattle: endocrinological changes and effects of timing on ovulation Zuchthygiene $18 \quad 172-177$

Cameron AWM and Batt PA (1991) PMSG may directly stimulate ovulation in female goats Animal Reproduction Science 25 233-239

Evans G and Robinson TJ (1980) The control of fertility in sheep: Endocrine and ovarian responses to progestagen-PMSG treatment in the breeding season and anoestrus Journal of Agricultural Science 94 69-88

Fennessy PF, Mackintosh CG and Shackell GH (1990) Artificial insemination of farmed red deer (Cervus elaphus) Animal Production 51 613-621 
Jabbour HN and Evans G (1991a) Ovarian and endocrine responses of Merino ewes to treatment with PMSG and/or FSH-P Animal Reproduction Science 26 93-106

Jabbour HN and Evans G (1991b) Ovarian and endocrine responses of Merino ewes following treatment with PMSG and GnRH or PMSG antiserum Animal Reproduction Science 259-270

Jabbour HN, Asher GW, Thompson JGE, Tervit HR and Morrow CJ (1990) Studies on superovulation and embryo recovery in farmed red and fallow deer. In The Biology of Deer pp 357 Ed. R Brown. Springer-Verlag, New York Jabbour HN, Asher GW, Smith JF and Morrow CJ (1992) Effect of progesterone and oestradiol benzoate on oestrus behaviour and secretion of luteinizing hormone in ovariectomized fallow deer (Dama dama) Journal of Reproduction and Fertility 94 353-361

Jabbour HN, Veldhuizen FA, Green G and Asher GW (1993) Endocrine responses and conception rates in fallow deer (Dama dama) following oestrous synchronization and cervical insemination with fresh or frozen-thawed spermatozoa Joumal of Reproduction and Fertility 98 495-502

Kelly RW, McNatty KP, Moore GH, Ross D and Gibb M (1982) Plasma concentrations of $\mathrm{LH}$, prolactin, oestradiol and progesterone in female red deer (Cerous elaphus) during pregnancy Journal of Reproduction and Fertility 64 475-483

McIntosh JEA, Moor RM and Allen WR (1975) Pregnant mare serum gonadotrophin: rate of clearance from the circulation of sheep Journal of Reproduction and Fertility 44 95-100

Magyar SJ, Biediger T, Hodges C, Kraemer DC and Seager SWJ (1989) A method of artificial insemination in captive white-tailed deer (Odocoileus virginianus) Theriogenology 31 1075-1080

Magyar SJ, Hodges CM and Kraemer DC (1990) Synchronization and superovulation in captive white-tailed deer. In The Biology of Deer Pp $356 \mathrm{Ed}$. R Brown. Springer-Verlag, New York
Monfort SL, Asher GW, Wildt DE, Wood TC, Schiewe MC, Williamson LR, Bush M and Rall WF (1993) Successful intrauterinè insemination in Eld's deer (Cerous eldi thamin) with frozen-thawed spermatozoa Journal of Reproduction and Fertility 99 459-465

Mulley RC, Moore NW and English AW (1988) Successful uterine insemination of fallow deer with fresh and frozen semen Theriogenology 29 1149-1153

Mylrea GE, Mulley RC, English AW and Evans G (1991) Seasonal response to progesterone and PMSG treatment in chital deer (Axis axis), a non-seasonal breeder Proceedings of the Australian Society for Reproductive Biology 23159

Ryan JR, Bilton RJ and Hunton IR (1984) Superovulation of ewes with a combination of PMSG and FSH-P. In Reproduction in the Sheep pp 338-341 Eds DR Lindsay and DT Pearce. Australian Academy of Sciences, Canberra

Scaramuzzi RJ, Caldwell BV and Moor RM (1970) Radioimmunoassay of LH and estrogen during the estrous cycle of the ewe Biology of Reproduction 3 110-119

Schoonmaker JN, Bergman KS, Steiner A and Karsch FJ (1982) Estradiol-induced luteal regression in the Rhesus monkey: evidence for an extra ovarian site of action Endocrinology 110 708-715

Thompson JGE and Asher GW (1988) Superovulation and ova recovery in farmed fallow deer (Dama dama) Proceedings of the Australian Society for Reproductive Biology 204

Thompson JGE, Simpson AC, James RW and Tervit HR (1990) The application of progesterone-containing CIDR devices to superovulated ewes Theriogenology 33 1297-1304

Whyman D and Moore RW (1980) Effects of PMSG and the prostaglandin $F_{2 \alpha}$ analogue, cloprostenol, on superovulation, fertilization and egg transport in the ewe Journal of Reproduction and Fertility 60 267-272

Wiltbank JN (1966) Modification of ovarian activity in the bovine following injection of oestrogen and gonadotrophin Journal of Reproduction and Fertility Supplement 1 I-8 